\title{
Two-year apprenticeships for young people with learning difficulties: a cost-benefit analysis for training firms
}

\author{
Marc Fuhrer, Jürg Schweri * \\ Swiss Federal Institute for Vocational Education and Training SFIVET
}

\begin{abstract}
Education policymakers are currently faced with the challenge of enabling young people with learning difficulties to achieve an upper-secondary level qualification. Switzerland has introduced a new type of combined school/ work-based VET programme that lasts two years. One of the key pre-requisites for success of two-year VET programmes is the willingness of host companies to create an adequate number of apprenticeship positions. We therefore examine the costs and benefits of two-year VET programmes for a sample of 409 host companies. Our main findings indicate that, on average, the value of the productive output of apprentices in two-year VET programmes slightly exceeds the overall costs of the training provided by host companies. Firms that operate in a competitive market are thus able to provide apprenticeship training to less capable young people.
\end{abstract}

Keywords: apprenticeship, training system, learning difficulties, cost-benefit analysis, employers

\section{Introduction}

Rapid developments within the economy are giving rise to an ever-increasing demand for qualifications on the labour market. As a result, policymakers in industrialised nations are now faced with the challenge of enabling as many individuals as possible to take part in post-compulsory education and training (upper-secondary level). According to the OECD (2009, Tab. A1 .2a), 79\% of all 25-34-year-olds held an upper-secondary level qualification in 2007 , compared to $81 \%$ within the $19 \mathrm{EU}$ member states. The more this proportion increases, the more pressing it becomes to decide which forms of education and training are suitable for young people with learning difficulties. In the past, such individuals would not have completed any form of post-compulsory education or training at all. In most countries, they are offered programmes oriented towards social welfare, or enrolled in vocational training

\footnotetext{
* Corresponding author: SFIVET, Kirchlindachstrasse 79, 3052 Zollikofen, E-mail: juerg.schweri@ ehb-schweiz.ch. The authors gratefully acknowledge the financial support provided by the Swiss Federal Office for Professional Education and Training (OPET).
} 
that «is often not related to real employment practice; it often takes place in segregated provision and it is not usually oriented towards complex professions» (European Agency for Development in Special Needs Education 2006, 69). However unsatisfactory these two options may be, if national education policies disregard individual aptitudes and circumstances for the sake of including all young people in mainstream forms of education, the risk of dropouts increases.

Taking advantage of an education system that has extensive upper-secondary level dual VET programmes, Switzerland has chosen a different course of action that constitutes a departure from social programmes and the segregated provision of entirely school-based VET. The proportion of holders of an upper secondary-level qualification among the Swiss inhabitants between the ages of 25 and 34 currently stands at $90 \%$ (OECD, 2009). While the main focus of the 1990s was placed on expanding education and training prospects for capable young people in the VET sector (i.e. by introducing the Federal VET Baccalaureate and universities of applied sciences), the focus over the past ten years has been on taking measures to ensure that the proportion of holders of upper secondary-level qualifications reaches $95 \%$. One such measure introduced by the Federal Vocational Education and Training Act is two-year vocational education and training. Like the three-year and four-year counterparts, two-year VET programmes involve a specific occupational profile, include a high proportion of work-based training in host companies and lead to issuance of a federally recognised qualification. By introducing two-year VET programmes into the existing apprenticeship market, young people with learning difficulties (i.e. the target group) should find it easier to complete post-compulsory education and training. The apprenticeship market brings together the demand side (i.e. host companies offering two-year, three-year and/or four-year apprenticeships) and the supply side (i.e. young people seeking apprenticeships for the VET programmes that they wish to enrol in). In the case of the two-year VET programme, if a suitable match is found, an irrevocable two-year apprenticeship contract is signed by both parties to the agreement: the prospective VET student and the host company.

Although faced with major challenges, this two-year dual VET model provides a number of distinct advantages. For one thing, it is the host companies themselves that decide whether to offer such apprenticeships. This ensures that the content of the apprenticeships closely matches the actual needs of the labour market. The state benefits in two ways: VET students receive education and training that increases their employment prospects, thereby reducing social insurance expenditure in the form of welfare or unemployment benefits; at the same time, dual VET programmes lower public education expenditure since most of the content of dual VET is workbased (i.e. provided by host companies on their premises and using their resources). These benefits can only be achieved, however, if two pre-conditions are met: Firstly, host companies must be willing to provide an adequate number of two-year apprenticeships, even though the target group for two-year VET programmes may not be 
comprised of the most ideal candidates. Secondly, the quality of two-year VET programmes must be good enough to increase the employability of VET graduates compared to individuals who do not complete any form of post-compulsory education and training.

This paper examines the first of the above-mentioned aspects, namely: is it possible for host companies to offer economically viable apprenticeships for two-year VET programmes? We conducted an empirical analysis of 409 host companies in Switzerland to answer the following key questions:

(1) Are host companies able to cover the costs of their involvement in two-year VET programmes through the productive work done by VET students during their apprenticeships? What is the cost-benefit ratio of two-year VET programmes compared to that of existing three-year and four-year VET programmes?

(2) Do the costs and benefits differ from one VET occupation to another?

(3) In addition to existing differences between individual occupations, what other factors influence the costs and benefits of two-year apprenticeships?

Our study comes to the conclusion that the revenues generated by the productive output of VET students are slightly higher than the cost of providing work-based training. Host companies are therefore able to achieve a small net profit from their involvement in two-year VET programmes. That said, net benefits for two-year VET apprenticeships are somewhat lower than for three-year and four-year VET apprenticeships. Moreover, in the two-year VET programmes for the 11 VET occupations considered, cost-benefit ratios varied considerably from one VET occupation to another.

This paper has been structured as follows: Chapter 2 discusses the theory and existing literature used as a frame of reference for our research. We also present how the cost-benefit analysis calculation was performed. Chapter 3 provides details regarding the Swiss education system and outlines the structure and content of two-year VET programmes. Chapter 4 describes how we went about gathering and analysing the data. Chapter 5 provides a descriptive and multivariate analysis of our findings. Finally, Chapter 6 provides a summary conclusion of our research findings.

\section{Analytical framework}

\subsection{Theory and related literature}

Cost-benefit analyses in the VET sector are based on Becker's human capital theory (1964). While this theory primarily focuses on «on-the-job training», it also lends itself to vocational education and training. 
As far as human capital theory is concerned, a distinction is drawn between general and specific human capital. General human capital consists of skills that employees are able to put to productive use both within the company in which the skills were acquired as well as within other companies. Employees who have acquired general human capital are therefore rewarded in the form of a higher wage (in competitive labour markets where wage equals productivity). Companies have little incentive to pay for the acquisition of general human capital since they will either have to pay the newly trained employee a higher wage or will end up losing that employee to another company that is willing to pay higher wages.

Firm-specific human capital, on the other hand, cannot be put to productive use within a different company. This means that employees will gain no benefits from the human capital if they choose to work for a different employer. Companies therefore have a greater incentive to pay for the acquisition of company-specific human capital since the risk of losing their employee to a higher-paying competitor will be much lower.

If apprentices mainly acquire general human capital in a given VET programme, host companies are able to cover the costs of work-based training by having VET students perform productive labour at a lower salary than what they would otherwise have to pay to a more qualified worker. If, on the other hand, apprentices mainly acquire firm-specific human capital in a given VET programme, host companies are able to derive an added benefit by hiring fully trained VET students upon completion of the apprenticeship. The specific human capital VET students acquire will benefit the company in the form of increased productivity.

The available literature is based on the premise that dual VET programmes in German-speaking countries usually impart general human capital (e.g. Acemoglu \& Pischke, 1999a). Despite the similarities of the VET systems in Germany, Austria and Switzerland, empirical studies into the costs of VET programmes reveal major differences: Studies conducted by the German Federal Institute for Vocational Education and Training (BIBB) revealed that host companies incur significant net costs from VET apprenticeships (von Bardeleben, 1995; Beicht et al., 2004), even though the latest cost-benefit study from Germany indicates that the proportion of host companies deriving a net benefit from VET apprenticeships has risen slightly (Wenzelmann et al., 2009). A study conducted in Austria also revealed a cost overhang, but the extent of this was lower than in Germany (Lassnigg \& Steiner, 1997). In the case of Switzerland, studies based on the same research methods showed that two-thirds of all host companies derive a net benefit from VET apprenticeships even before VET students have completed their three-year or four-year VET programme (Schweri et al., 2003; Mühlemann et al., 2007a). What is more, Wolter et al. (2006) and Mühlemann et al. (2007b) provide evidence that the anticipated cost-benefit ratio is a decisive factor in the willingness of host companies to offer VET apprenticeships. According to Mühlemann et al. (2010), the differences between German and 
Swiss outcomes can be explained by the fact that the Swiss labour market is not as heavily regulated as the German one. As a result, the predictions made in Becker's human capital theory closely match the observations made in the Swiss empirical study. In Germany, on the other hand, the labour market is strictly regulated, which gives rise to frictions within the labour market. Acemoglu and Pischke (1999a, 1999b) show that, under certain circumstances, such frictions may offer an incentive to companies to pay for the acquisition of general human capital. Such companies are able to derive a net benefit by paying trained workers wages that are lower than the actual value of their productive output.

Like their three-year and four-year counterparts, two-year VET programmes in Switzerland are designed to enable apprentices to develop skills that relate to an occupation and not to an individual company. Based on Becker's theory, it can therefore be expected that training costs will be borne by the VET students themselves. Within the context of this study, we shall seek to determine whether, on average, two-year VET programmes in Switzerland can be operated as cost-effectively as three-year and four-year VET programmes.

\subsection{Cost-benefit model}

In order to establish the costs and benefits of host companies offering two-year apprenticeships, the same model was used as the one used in the previously mentioned literature relating to Germany, Austria and Switzerland (see Mühlemann et al., 2007a for example). The cost-benefit ratio (i.e. net result) at the end of the VET programme is therefore calculated by subtracting the gross costs incurred by host companies from the productive output of VET students during their apprenticeship.

Broadly speaking, the gross costs incurred by host companies fall into one of five categories:

- Apprenticeship wages

- Cost of VET trainers ${ }^{1}$ (salaries of VET trainers times the amount of training time invested)

- Personnel costs for administration and recruitment

- Costs for equipment, furniture, training materials

- Miscellaneous costs (e.g. fees for industry courses)

The principle of opportunity costs forms the basis for the calculation of work-based training benefits. The basic assumption is that apprentices perform duties at the host company that would have to be performed anyway by other types of employees. Here, a distinction is drawn between skilled tasks that can only be performed by

1 Note that «trainers» are predominantly workers of the companies that assume the part-time function of trainers besides their regular work for the company. 
skilled workers and unskilled tasks that can be performed by unskilled workers. Host companies were therefore asked how much of apprenticeship time is devoted to performing skilled tasks and how much time is devoted to unskilled tasks. As far as the skilled tasks are concerned, the companies were also asked to compare performance levels achieved by VET students with those achieved by skilled workers employed by the same company and in the same occupation. The amount of apprenticeship time devoted to each type of task was then offset against the salaries of the relevant categories of employees. The result of these calculations determines the value of the productive work done by VET students.

The net result is equivalent to the difference between productive output and gross costs: If productive output exceeds gross costs, a net benefit results. If the opposite holds true, then the host company has incurred net costs. ${ }^{2}$

\section{Institutional context}

In Switzerland, around $70 \%$ of all young people coming out of lower-secondary education enrol in an upper secondary-level VET programme. Nearly $90 \%$ of these students opt for the combined school/work-based form (i.e. dual VET programmes) and only $10 \%$ for the entirely school-based one. ${ }^{3}$ With dual VET programmes, VET students enter into an apprenticeship contract with a host company for a period of three or four years (depending on the occupation upon which the VET programme is based); during that period, VET students attend a VET school for one or two days a week, and they work at the host company for three to four days a week. At the age of 16 , young people are able to choose from approximately 250 different VET occupations, all of which have been defined at federal level in the form of a specific VET ordinance. Each VET ordinance states the name of the occupation, the duration of the programme, the skills and competencies to be acquired by students by the end of the programme and the final examination procedures for issuance of a federally recognised and protected qualification. VET apprenticeships are highly regarded on the Swiss labour market, as is shown by a rate of return on education of around 7\% (Weber et al., 2001). Research has devoted a certain amount of attention to the apprenticeship dropout phenomenon (Masdonati et al., 2010; Stalder \& Schmid, 2008); with dropouts accounting for $7 \%{ }^{4}$ of all apprenticeship contracts, the percentage is

2 For the purpose of this study, post-apprenticeship benefits derived by host companies as a result of hiring their VET students at the end of their apprenticeship (see Wolter \& Schweri, 2002) have not been taken into account. Since two-year VET programmes for certain occupations were developed only fairly recently, over half of the host companies surveyed had not yet had an opportunity to hire own VET graduates from two-year apprenticeships.

3 For details regarding the Swiss VET sector, see Hoeckel et al. (2009).

4 According to Stalder and Schmid (2006), the proportion of VET students in the Canton of Bern who terminate their apprenticeship contracts prior to completion of their VET programme is around $20 \%$. According to Stalder and Schmid (2008), around one-third of these students will not obtain any further qualification. 
not all that high. However, if the objective is to ensure that as many young people as possible obtain an upper-secondary level qualification, then this percentage cannot be disregarded.

The Federal Vocational Education and Training Act of 2002 (SR 412.10) created two-year VET programmes leading to issuance of the Federal VET Certificate. These two-year VET programmes leading to issuance of the Federal VET Certificate (Eidgenössisches Berufsattest) are primarily intended for young people who demonstrated lower scholastic aptitudes in lower-secondary school and who are unlikely to make it through an upper-secondary level three-year or four-year VET programme. Two-year VET programmes also place emphasis on practical activities (OPET, 2005).5 Like three-year or four-year VET programmes, two-year VET programmes also entail signing an apprenticeship contract with a host company.

Like the three-year and four-year VET programmes, which lead to issuance of the Federal VET Diploma, all two-year VET programmes have their own VET ordinance and corresponding training plan. Two-year VET programmes are therefore not short courses or mini-apprenticeships covering the first two years of existing training programmes. They are an entirely new form of training with an occupational profile of their own. It is the professional organisations that decide whether to create a twoyear VET programme for a given occupation. They also play a leading role in the committees set up to draft individual VET ordinances and training plans. The active involvement of professional organisations ensures that each new two-year VET programme fills an actual need within the labour market.

Unlike three-year or four-year VET programmes, students enrolled in a two-year VET programme are entitled to receive individual support services if they encounter any difficulties that may jeopardise their chances of obtaining the Federal VET Certificate. These support services are provided by the Cantons to prevent young people from terminating their apprenticeship contract prior to completion of the VET programme. At the end of their apprenticeship, VET students undergo a qualification procedure (i.e. final apprenticeship examination) to obtain the Federal VET Certificate. ${ }^{6}$ Upon successful completion of a two-year VET programme, VET graduates

5 The OECD (2005) draws a distinction between students with disabilities, students with learning difficulties, and students with disadvantages. Two-year VET programmes are primarily directed towards the last two groups of people. In Switzerland, students with disadvantages are frequently young people with a migration background, often from families of low socio-economic status. Such students may also have linguistic problems that simultaneously engender learning difficulties.

6 This reveals a discrepancy between existing perceptions in Switzerland and those at the international level. While the main purpose of a two-year VET programme is to enable VET students to obtain an upper-secondary-level qualification, such programmes are classified at level 3C in the ISCED classification. As a result, the OECD does not consider the Federal VET Certificate to be an upper-secondary level qualification and therefore excludes holders of this qualification in its statistics. The figures presented in our introduction are therefore incomplete. The criterion used to allocate two-year VET programmes to level $3 \mathrm{C}$ instead of $3 \mathrm{~B}$ is that the qualification must not entitle the holder to gain im- 
are then entitled to obtain advanced placement in a three-year or four-year VET programme (reduction of one year with respect to the normal duration). This provides graduates of two-year VET programmes with an appropriate route of progression towards more advanced VET.

The number of two-year VET programmes is constantly increasing. By mid-2010, prospective students could choose from among 29 VET occupations. For the training year that began in August 2009, two-year VET programmes represented $6.25 \%$ of all apprenticeship contracts entered into at that time (FSO, 2010).

Very little research has thus far been published regarding these two-year VET programmes. A longitudinal survey of graduates of two-year VET programmes (Kammermann, 2010) shows that they enjoy better employment and earning prospects than individuals who took part in upper-secondary two-year basic apprenticeships (Anlehren) under the previous system that lacked a standardised occupational profile and thus a certificate generally recognised on the labour market.

The question regarding the cost-benefit ratio is an obvious one to ask in relation to two-year VET programmes. For one thing, the nature of the target group leads us to assume that the expense incurred by host companies may well be higher than what they would otherwise incur with three-year or four-year VET programmes. Moreover, the perception of two-year VET programmes as being low-threshold may give rise to concerns that host companies will not really help VET students to develop useful vocational skills but will merely use them as cheap labour. For this reason, the outcome of two-year programmes in comparison to three- or four-year programmes remains unclear a priori.

With this in mind, we set out to answer the following questions:

(1) Are host companies able to cover the costs of their involvement in two-year VET programmes through the productive work done by VET students during their apprenticeships? What is the cost-benefit ratio of two-year VET programmes compared to that of existing three-year and four-year VET programmes?

(2) Do the costs and benefits differ from one VET occupation to another?

(3) In addition to existing differences between individual occupations, what other factors influence the costs and benefits of two-year apprenticeships?

mediate admission to education and training at ISCED 5B level. Excluding ISCED 3C programmes from the statistics on the basis of this criterion does not make much sense for this target group since the primary objective is for students to obtain at least an ISCED level 3 qualification, irrespective of an eventual further education at a higher level later on. 


\section{Data}

Data were gathered from host companies for the following 11 VET occupations (in alphabetical order): Automotive assistant, Carpentry assistant, Dairy assistant, Domestic assistant, Hotel employee, Kitchen employee, Logistics assistant, Metalworker, Restaurant employee, Retail assistant and Tyre worker. These occupations correspond to the two-year VET programmes that had been introduced by 2007 and for which we were certain that some host companies had experienced both apprenticeship years at the time of our survey.

\subsection{Data collection}

The cost-benefit data were collected by means of an online questionnaire which is an online version of the paper and pencil questionnaire used by the University of Berne for its study of cost-benefit ratios for three-year and four-year VET programmes leading to issuance of the Federal VET Diploma (Mühlemann et al., 2007a). We made a few minor changes to this questionnaire in order to take into account various distinctive features of two-year VET programmes and their impact on the corresponding cost-benefit ratio.

The addresses of the host companies were taken from the records held by the Federal Statistical Office (FSO). The questionnaire was sent to 2,599 companies in the Swiss German-speaking and French-speaking regions of Switzerland. The response rate of approximately $16 \%$ fell within the usual range for company surveys involving detailed questionnaires.

The sample used for our study is described in Table 1 below.

Table 1: Composition of sample

\begin{tabular}{llcc}
\hline Variable & Specification & N & Percentage of sample \\
\hline Company size & $1-9$ employees & 190 & 46.45 \\
& $10-49$ employees & 148 & 36.19 \\
& $50-99$ employees & 36 & 8.80 \\
& $100+$ employees & 35 & 8.56 \\
\hline VET occupation & Automotive assistant & 62 & 15.16 \\
(in alphabetical order) & Carpentry assistant & 38 & 9.29 \\
\hline
\end{tabular}

7 When calculating productive output levels, we were unable to compare the productive output of students enrolled in two-year VET programmes with that of graduates of two-year VET programmes since virtually no such graduates existed in the host companies at the time we conducted our study. In order to designate a suitable category of employee to be used as a frame of reference, we asked the host companies which category of employee would handle the skilled tasks if the company did not train VET students. 


\begin{tabular}{llrr}
\hline & Dairy assistant & 7 & 1.71 \\
& Domestic assistant & 21 & 5.13 \\
& Hotel employee & 13 & 3.18 \\
& Kitchen employee & 38 & 9.29 \\
& Logistics assistant & 33 & 8.07 \\
& Metalworker & 24 & 5.87 \\
& Restaurant employee & 21 & 5.13 \\
& Retail assistant & 125 & 30.56 \\
& Tyre worker & 27 & 6.60 \\
& & & 91.20 \\
\hline Linguistic region & German & 373 & 8.80 \\
& French & 36 & 89.00 \\
\hline Private or public sector & Private sector & 364 & 11.00 \\
& Public sector/Non-profit & 45 & \\
\hline Total number of & & & \\
companies (N) & & 409 & \\
\hline
\end{tabular}

An initial plausibility check was automatically performed on all of the data gathered while the data were being entered into the computer. A second plausibility check was then performed after data gathering was complete. Some 280 host companies were then contacted by telephone to request details for items that were missing or to correct figures that seemed implausible. In this manner, we were able to significantly improve data quality. ${ }^{8}$

\section{Results}

\subsection{Summary of cost-benefit analysis}

On average, host companies incurred gross costs of $€ 17,317^{9}$ in the first year of the two-year VET programme and $€ 19,179$ in the second year. These gross costs are slightly higher than the gross costs incurred for the first two years of three-year and four-year VET programmes leading to issuance of the Federal VET Diploma (see Mühlemann et al., 2007a). Apprenticeship salaries, which account for almost onehalf of the gross costs, are roughly the same for two-year, three-year and four-year VET programmes. The higher costs for two-year VET programmes can primarily be attributed to the higher cost of VET trainers and to a lesser extent to the higher costs of administering two-year apprenticeships. The higher cost of VET trainers is worth mentioning: On average, the amount of time devoted to training apprentices during

8 For further details regarding the research design, see Fuhrer and Schweri (2010).

9 The calculations in this study are based on Swiss francs. An exchange rate of $1 \mathrm{CHF}=0.66 €$ was used to convert Francs to Euros. 
the first year of a two-year VET programme is half an hour longer and in the second year a full hour longer than for the first and second years of three-year VET programmes. This may mean that the target group for the two-year VET programmes requires additional training supervision. Seen in a more positive light, it also means that host companies take their training responsibilities seriously and are not seeking to cut costs in relation to training supervision.

The mean benefit that host companies derive from the productive output of VET students during two-year VET programmes is shown in Table 2. During the first year of work-based training, most of the productive work done by VET students relates to tasks that would otherwise have been handled by unskilled workers. In the second year of work-based training, however, VET students are asked to perform a larger number of skilled tasks that would otherwise have been handled by skilled workers. The time devoted to these skilled tasks should be considered as well as the performance level that apprentices achieve compared to a skilled worker in the company. The data show that both the extent of skilled tasks and the performance level are higher during the second year of training. It is also worth noting that VET students devote $53 \%$ of their time within the company to skilled tasks during the second year, the rest being accounted for by unskilled productive tasks and non-productive time (e.g. exercises).

Based on the information provided by the host companies, VET students are not merely being used to do work normally undertaken by unskilled workers or doing non-productive exercises. This seems to indicate, therefore, that VET students are acquiring real hands-on vocational skills, which may be of use to them on the labour market at a later stage.

Table 2: Productive output (in Euro)

\begin{tabular}{lccc}
\hline & First year & Second year & Total \\
\hline Tasks otherwise performed by unskilled workers & 9,429 & 8,344 & 17,773 \\
Tasks otherwise performed by skilled workers & 7,657 & 11,345 & 19,002 \\
\hline Total productive output & 17,086 & 19,689 & 36,775 \\
\hline
\end{tabular}

If we subtract productive output from the gross costs, we obtain the net result. Table 3 shows that on average, host companies narrowly achieve a net benefit. On average, however, the costs during the first year of training exceed the benefits. Moreover, the total net benefit of $€ 279$ over a two-year period is not significantly different from zero. 
Table 3: Summary of costs and benefits (in Euro)

\begin{tabular}{lccccc}
\hline & First year & Second year & Total & 25\%-Quantil & 75\%-Quantil \\
\hline Production output & 17086 & 19689 & 36775 & 29658 & 44165 \\
Gross costs & 17317 & 19179 & 36496 & 26819 & 42578 \\
\hline Net results & -231 & 510 & 279 & -8560 & 12380 \\
\hline
\end{tabular}

The cost-benefit figures calculated using the detailed information provided by host companies in our study match the estimates provided by the host companies themselves regarding their level of satisfaction with the cost-benefit ratio of work-based training. On a scale of one to five, two-thirds of the host companies stated that they were fairly or very satisfied, while fewer than $14 \%$ of the host companies were fairly or very dissatisfied.

The first finding of our study is that, on average, there is no cost overhang for host companies at the end of the two-year VET programme. On average, host companies manage to recover all of their work-based training costs through the productive output of VET students over the course of the two-year apprenticeship. ${ }^{10}$ This in itself confirms the prediction made by Becker's human capital theory, namely that apprentices pay for their own training.

Nevertheless, there is considerable spread in the two quartiles listed in Table 3. While $55 \%$ of the host companies certainly managed to obtain a net benefit, the remaining $45 \%$ did not. This spread could possibly be explained by the fact that twoyear VET programmes were only developed fairly recently which may have led to a large heterogeneity between the training schemes in different companies. In addition, judging from queries in response to the questionnaires and follow-up telephone calls, performance levels among VET students vary considerably, leading to corresponding variations in both their productive output and the amount of training supervision required.

Table 4: Summary of costs and benefits of Federal VET Certificate versus Federal VET Diploma (in Euro)

\begin{tabular}{|c|c|c|c|}
\hline \multicolumn{4}{|c|}{ Federal VET Certificate, two-year VET programme } \\
\hline & First year & Second year & Total \\
\hline Production output & 17086 & 19689 & 36775 \\
\hline Gross costs & 17317 & 19179 & 36497 \\
\hline Net result & -231 & 510 & 279 \\
\hline
\end{tabular}

10 It is important to note that the two-year VET programmes in question were only developed recently and that host companies may also incur one-time initial expenses that are included in these figures. It is therefore possible that the average gross costs may decrease in the medium term. 


\begin{tabular}{|c|c|c|c|c|c|}
\hline \multicolumn{6}{|c|}{ Federal VET Diploma, three-year VET programme } \\
\hline & First year & Second year & Third year & & Total \\
\hline Production output & 17877 & 19831 & 24373 & & 62080 \\
\hline Gross costs & 16535 & 17276 & 20101 & & 53912 \\
\hline Net result & 1342 & 2555 & 4271 & & 8168 \\
\hline \multicolumn{6}{|c|}{ Federal VET Diploma, four-year VET programme } \\
\hline & First year & Second year & Third year & Fourth year & Total \\
\hline Production output & 12470 & 15229 & 21899 & 27394 & 76992 \\
\hline Gross costs & 17408 & 17429 & 19091 & 21664 & 75592 \\
\hline Net result & -4938 & -2199 & 2807 & 5730 & 1400 \\
\hline
\end{tabular}

Table 4 enables comparisons between the results obtained for two-year VET programmes and the results obtained by Mühlemann et al. (2007a) for three-year and four-year VET programmes. ${ }^{11}$ Table 4 shows that the net benefits exceed the gross costs for two-year, three-year and four-year VET programmes and that it is the threeyear VET programmes that are the most economically viable. For their part, fouryear programmes involve exacting technical apprenticeships, which generate net costs for host companies in the first two years of training. The third and fourth year of training, however, serve the purpose of repaying that investment, as VET students are the most productive in their final year(s) of their apprenticeship. With two-year VET programmes, however, host companies have only two years to achieve a balance between the costs and benefits of providing work-based training. It should therefore come as no surprise that, on average, two-year VET programmes are less economically advantageous than three- and four-year ones.

\subsection{Results by occupation}

Table 5 shows the average net results, itemised according to each of the individual occupations analysed. ${ }^{12}$

In some cases, these figures reveal sizeable deviations from the mean for all occupations. The highest net costs were found in occupations relating to the hotel, restaurant and catering sector. The high net costs are mainly attributable to above-average wages paid to apprentices. This is despite the fact that low wages are considered the norm in the hotel, restaurant and catering sector. The high wages paid to apprentices, however, were established on the basis of a collective labour agreement and may

11 In undertaking this general comparison, VET programmes in very different occupations and sectors are compared with one another. Nevertheless, the statements made in this section also apply when we compare two-year, three-year and four-year VET programmes in the same occupational field. See Fuhrer and Schweri (2010).

12 Due to the small number of individuals involved, the occupations of hotel employee and dairy worker could not be assessed separately and have therefore been omitted from this table. 
also be partly explained by the tradition that apprentices normally receive their wages minus board (and sometimes room). The apprenticeship wages would be somewhat overestimated if the market value of these benefits in kind were lower than the actual amounts deducted from apprenticeship salaries.

Table 5: Net results by occupation

\begin{tabular}{lccccc}
\hline & First year & Second year & Total & First quartile & Third quartile \\
\hline Automotive assistant & -2321 & -1275 & -3596 & -13595 & 7519 \\
Retail assistant & 935 & 2572 & 3507 & -6114 & 15633 \\
Domestic assistant & -1281 & -1995 & -3276 & -12083 & 9483 \\
Kitchen employee & -3584 & -3514 & -7098 & -23788 & 8241 \\
Logistics assistant & 230 & 3306 & 3536 & -3511 & 12669 \\
Metal worker & -774 & 404 & -370 & -5734 & 15401 \\
Tyre worker & 4416 & 5847 & 10263 & 2516 & 19837 \\
Restaurant employee & -3078 & -5286 & -8364 & -15729 & 1661 \\
Carpentry assistant & 795 & 1083 & 1878 & -4968 & 12424 \\
\hline
\end{tabular}

The occupations of logistics assistant and tyre worker can be found at the opposite end of the extreme. The high net benefit found in these occupations can mainly be attributed to the high productive output.

It is also interesting to compare the occupations of automotive assistant and tyre worker, each of which can be assigned to the same economic sector. While there is hardly any difference in gross costs between these two occupations, a difference in excess of $€ 13,000$ in terms of productive output is striking. Further differences between occupations can also be observed in the multivariate analyses described in the next chapter.

\subsection{Multivariate analyses}

In the analyses presented thus far, we found a broad spread between host companies and a significant difference between the mean values for individual VET occupations. The next step is to determine whether it is the VET occupations themselves that are responsible for these differences and whether other factors may affect the cost-benefit ratios obtained by the host companies involved. In order to achieve these two objectives, this chapter examines the variables «net benefit», «productive output» and «gross costs». 
Table 6: Multivariate analyses of net results, productive output and gross costs (OLS)

\begin{tabular}{|c|c|c|c|}
\hline & Net benefit & $\begin{array}{l}\text { Productive } \\
\text { output }\end{array}$ & Gross costs \\
\hline French-speaking region of Switzerland & -3299 & -133 & 3166 \\
\hline 10-49 employees & -450 & $3195 * * *$ & $3645^{* *}$ \\
\hline 50-99 employees & -335 & 3854 & 4189 \\
\hline 100+ employees & -4432 & 2963 & $7395 * * *$ \\
\hline Total number of apprentices & $1100 *$ & 127 & $-973 * *$ \\
\hline$(\text { Total number of apprentices) })^{2}$ & $-15^{*}$ & -3 & $12^{*}$ \\
\hline Automotive assistant & $-7033 * * *$ & $-5128 * * *$ & 1905 \\
\hline Carpentry assistant & -1335 & 1011 & 2346 \\
\hline Domestic assistant & -3680 & 4235 & $7915 * *$ \\
\hline Kitchen employee & $-8688 * * *$ & 2946 & $11634 * * *$ \\
\hline Logistician (Federal VET Certificate) & 1577 & $7167 * * *$ & $5590 * *$ \\
\hline Metal worker & -4008 & 2417 & $6425 * *$ \\
\hline Restaurant employee & $-10954 * * *$ & 1577 & $12531 * * *$ \\
\hline Tyre worker & 5343 & $7915 * * *$ & 2572 \\
\hline Other occupations & -4640 & $4927 * *$ & $9567 * * *$ \\
\hline $\begin{array}{l}\text { Difficulties in finding qualified applicants for } \\
\text { apprenticeships }\end{array}$ & $-5084 * * *$ & -1337 & $3747 * *$ \\
\hline $\begin{array}{l}\text { Intending to hire VET students as employees at } \\
\text { the end of the apprenticeship (retention strategy) }\end{array}$ & 1116 & 741 & -375 \\
\hline Sector: Administration/Non-Profit & -2418 & $-3029 * *$ & -611 \\
\hline Constant & -1575 & $27800 * * *$ & $29375 * * *$ \\
\hline Number of observations (N) & 409 & 409 & 409 \\
\hline R-squared & 0.12 & 0.17 & 0.18 \\
\hline
\end{tabular}

* significant at $10 \%$ level of significance ** significant at $5 \%$; *** significant at $1 \%$

Reference company: Swiss German-speaking region of Switzerland, 1-9 employees, providing work-based training for the occupation of retail assistant, private sector

The first column in Table 6 contains the non-standardised coefficients of an ordinary least squares regression for the dependent variable «net benefit». The second column shows the results for the same model, this time using the dependent variable «productive output». The third column shows the gross costs. This enables us to observe whether the impact of independent variables on the net results in the first column occur primarily as a result of effects on productive output or on gross costs.

The most interesting items are the coefficients that relate to each individual VET occupation. On the basis of this, we can largely confirm the picture described in Section 5.2. If we also examine additional variables, the occupations in the hotel, restaurant and catering sector remain the most expensive ones for host companies. The reason for this lies in the above-average gross costs (see Table 6, third column). Another VET occupation that is also significantly more costly than the reference oc- 
cupation of retail assistant is that of automotive assistant, where productive output is below average. The only occupations that provide a higher return than that of a retail assistant are the occupations of logistician and tyre worker. While the effect for both occupations is not statistically significant, the production output of both occupations is above average, and those effects are significant.

We also analysed the number of apprentices in each of the host companies surveyed. The weakly significant effects of the number of apprentices and the square of the number of apprentices show that a company is able to generate a greater benefit for itself per head if it takes on more apprentices. However, this effect gradually decreases as the number of apprentices increases. This effect of the number of apprentices on the net results can be attributed to lower gross costs rather than to productive output. It is thus possible to achieve economies of scale in the provision of training to young people in two-year VET occupations.

The variable associated with difficulties in recruitment indicates whether or not companies experienced difficulties in finding suitable applicants for apprenticeships. According to the regression results, companies that had difficulty finding qualified apprentices will derive significantly lower benefits due to the higher gross costs. One possible explanation would be that, to some extent, these companies had to choose from among applicants that they did not regard as ideal. They therefore had to accept that the effort and thus cost required to provide work-based training would be slightly greater. This explanation matches the results obtained by Fuhrer and Wolter (2007), who concluded that with those three-year and four-year VET occupations that result in net benefits during training, apprentices of lower ability (based upon the grades received in school) require greater training supervision. It is presumed that host companies will eventually be able to reach a situation where apprentices perform tasks to a sufficiently high standard to undertake productive work. Nevertheless, there is also an alternative explanation. Those companies who indicated that they experienced recruitment difficulties could well be the same ones that have particularly stringent skills requirements. These companies generally need better-trained employees. They would therefore provide more intensive work-based training to VET students in two-year apprenticeships than other companies would, independently from the difficulties to find qualified applicants.

Whether or not companies aim at providing permanent employment to successful apprentices has no effect at all on the net results. In other words, host companies which want to hire several or most of their apprentices at the end of the apprenticeship end up devoting roughly the same amount of resources to VET apprenticeships as other host companies that only intend to hire apprentices on an exceptional basis.

The results show that the greatest differences in cost-benefit ratios can be attributed to the various VET occupations. Nevertheless, the circumstances associated with the 
training (difficulties in finding qualified applicants for apprenticeships, the number of apprentices), coupled with company features (company size) also play a role.

\section{Conclusion}

This study is the first to examine cost-benefit ratios for host companies involved in two-year VET programmes leading to issuance of the Federal VET Certificate. On average, the host companies managed to derive a net benefit from the work-based training they provide. However, this net benefit is close to zero and not significantly different from zero.

This finding nevertheless shows that it is possible for host companies that operate in a competitive market to train apprentices in two-year VET programmes leading to the Federal VET Certificate. This is, in itself, an accomplishment if we consider the target group for two-year VET programmes. Indeed, this target group is comprised of scholastic underachievers who would find themselves overstretched were they to proceed immediately from lower-secondary school into a full-fledged three-year or four-year VET programme.

Host companies are able to provide suitable work to these young people, as evidenced by their remarkable productive output. At the same time, the noticeable amount of time invested by trainers of the host firms indicates that apprentices are not solely being used as a cheap form of labour.

Considering the entire period of work-based training, we find that the net benefit for two-year VET programmes leading to issuance of the Federal VET Certificate is somewhat lower than the net benefit obtained for three-year and four-year VET programmes leading to issuance of the Federal VET Diploma. This also seems to be logical if we consider that the three-year and four-year VET programmes mainly become cost-effective in the final year of the apprenticeship.

The differences between two-year VET programmes for the eleven occupations considered are also striking. In this regard, the profile of two-year VET programmes does not differ from that of the profile of three-year or four-year VET programmes. As with two-year VET programmes, there are also considerable differences between individual occupations in three-year and four-year VET programmes.

The analysis also points to the limitations posed by two-year VET programmes. On average, host companies that have difficulties in finding qualified applicants for apprenticeships are not entirely able to cover gross costs through the productive output of apprentices. Two-year VET programmes are intended for young people with learning difficulties; yet, if host companies want to ensure that apprentices will be able to generate productive output and that work-based training can be conducted in a cost-effective manner, they nevertheless have to impose certain minimum require- 
ments with regard to apprenticeship applications. This implies that additional forms of training will be needed for young people who do not even fulfil the minimum requirements for two-year VET programmes.

Since the cost-benefit ratio is slightly positive, the economic incentive for companies to train young people in a two-year VET programme is present. It is clearly possible to promote the integration of young people with learning difficulties (at least partly) by means of a dual approach (i.e. market-based training programmes). The initial results from longitudinal studies also point to the fact that apprentices who successfully complete the two-year VET programme enjoy better employment prospects (Kammermann, 2010). In order to assess progress towards increasing the proportion of young people in Switzerland who obtain an upper secondary-level qualification, we first need to wait until two-year VET programmes have become firmly established and become more prevalent. Only then will it be possible to conduct an in-depth analysis of the development of work-based training activities of host companies. Over time, we should also be able to assess the value of the Federal VET Certificate on the labour market by determining its rate of return on education, for instance.

\section{References}

Acemoglu, D. \& Pischke, J.-S. (1999a). Beyond Becker: Training in Imperfect Labour Markets. Economic Journal, 109, F112-F142

Acemoglu, D. \& Pischke, J.-S. (1999b). The Structure of Wages and Investment in General Training. Journal of Political Economy, 107(3), 539-572

Becker, G. S. (1964). Human Capital. A Theoretical and Empirical Analysis with Special Reference to Education. Chicago: The University of Chicago Press

Beicht, U.; Walden, G. \& Herget, H. (2004). Kosten und Nutzen der betrieblichen Berufsausbildung in Deutschland. Bonn: Bundesinstitut für Berufsbildung (Berichte zur beruflichen Bildung, Heft 264)

European Agency for Development in Special Needs Education (2006). Special Needs Education in Europe (Vol.2) - Provision in Post-Primary Education. Odense: European Agency for Development in Special Needs Education

FSO (2010). Statistik der beruflichen Grundbildung 2009. Neuchâtel: Federal Statistical Office

Fuhrer, M. \& Schweri, J. (2010). Kosten und Nutzen von zweijährigen beruflichen Grundbildungen aus der Sicht der Betriebe. Schlussbericht. Zollikofen: EHB

Fuhrer, M. \& Wolter, S. (2007). Wird nur dem gegeben, der ohnehin schon hat? Panorama, (21)4, 15-16

Hoeckel, K., Field, S. \& Grubb, N. (2009). Learning for Jobs. OECD Reviews of Vocational Education and Training: Switzerland. Paris: OECD

Kammermann, M. (2010). Job or further training? Impact of the Swiss Basic Federal Vocational Education and Training (VET) Certificate on the careers of low achieving young people. Education + Training, 52(5), 391-403

Lassnigg L. \& Steiner, P. (1997). Die betrieblichen Kosten der Lehrlingsausbildung. Wien: Kammer für Arbeiter und Angestellte für Wien, Materialien zu Wirtschaft und Gesellschaft, Nr. 67

Masdonati, J.; Lamamra, N., \& Jordan, M. (2010). Vocational Education and Training Dropouts and the School-to-Work Transition. Education + Training, 52(5), 404-414

Mühlemann, S.; Wolter, S. C.; Fuhrer, M. \& Wüest, A. (2007a). Lehrlingsausbildung - ökonomisch betrachtet. Ergebnisse der zweiten Kosten-Nutzen-Studie. Zürich: Rüegger

Mühlemann, S.; Pfeifer, H.; Walden, G.; Wenzelmann, F. \& Wolter, S. C. (2010). The Financing of Apprenticeship Training in the Light of Labor Market Regulations. Labour Economics, 17(5), 799-809 
Mühlemann, S.; Schweri, J.; Winkelmann, R. \& Wolter, S. C. (2007b). An Empirical Analysis of the Decision to Train Apprentices. LABOUR: Review of Labour Economics and Industrial Relations, 21(3), 419-441

OECD (2005). Students with Disabilities, Learning Difficulties and Disadvantages. Statistics and Indicators. Paris: OECD

OECD (2009). Education at a Glance: OECD Indicators. Paris: OECD

OPET (2005). Zweijährige berufliche Grundbildung mit eidgenössischem Berufsattest. Leitfaden. Berne: Federal Office for Professional Education and Training

Schweri, J.; Mühlemann, S.; Pescio, Y.; Walther, B.; Wolter, S. \& Zürcher, L. (2003). Kosten und Nutzen der Lehrlingsausbildung aus der Sicht Schweizer Betriebe. Zürich: Rüegger

Stalder, B. E. \& Schmid, E. (2006). Lehrvertragsauflösungen, ihre Ursachen und Konsequenzen. Ergebnisse aus dem Projekt LEVA. Bern: BiEv

Stalder, B. E. \& Schmid, E. (2008). Lehrvertragsauflösung: Chancen und Risiken für den weiteren Ausbildungsweg. Ergebnisse aus dem Projekt LEVA. Bern: BiEv

Von Bardeleben, R.; Beicht, U. \& Fehér, K. (1995). Betriebliche Kosten und Nutzen der Ausbildung: repräsentative Ergebnisse aus Industrie, Handel und Handwerk. Bielefeld: Bertelsmann (Berichte zur beruflichen Bildung, Heft 187)

Weber, B. A.; Wirz, A. M. \& Wolter, S. C. (2001). Switzerland, In: C. Harmon, I. Walker, \& N. Westergaard-Nielsen (Eds.): Education and Earnings in Europe - A Cross Country Analysis of the Returns to Education. Cheltenham: Elgar, pp. 285-301

Wenzelmann, F.; Schönfeld, G.; Pfeifer, H. \& Dionisius, R. (2009). Betriebliche Berufsausbildung: Eine lohnende Investition für die Betriebe. Bonn: BIBB (BIBB-Report)

Wolter, S. C., Mühlemann, S. \& Schweri, J. (2006). Why some firms train apprentices and many others do not. German Economic Review, 7(3), 249-264

Wolter, S. C. \& Schweri, J. (2002). The Cost and Benefit of Apprenticeship Training: The Swiss Case. Applied Economics Quarterly, 48(3-4), 347-367 